\section{Cyclic Irrigation Reduces Container Leachate Nitrate-nitrogen Concentration}

\author{
Donna C. Fare ${ }^{1}$, Charles H. Gilliam ${ }^{2}$, and Gary J. Keever ${ }^{2}$ \\ Department of Horticulture, Auburn University, AL 36849 \\ John W. Olive ${ }^{3}$ \\ Ornamental Horticulture Substation, Mobile, AL 36689
}

Additional index words. Ilex crenata, pulse irrigation, intermittent irrigation, water quality, irrigation runoff

Abstract. Two experiments were conducted to evaluate the effects of cyclic irrigation on leachate $\mathrm{NO}_{3}-\mathrm{N}$ concentration, container leachate volume, total effluent volume, and growth of Ilex crenata Thunb. 'Compacta'. In Expt. 1, container leachate volume was reduced $34 \%$ when $13 \mathrm{~mm}$ of water was applied in three cycles compared to continuous irrigation of $13 \mathrm{~mm}$ per unit time. Forty-nine percent less container leachate volume was collected from a continuous application of $8 \mathrm{~mm}$ than from that of $13 \mathrm{~mm}$ water. In Expt. 2, container leachate volume was reduced $71 \%$ when $6 \mathrm{~mm}$ was applied in a single application over 30 minutes compared to $13 \mathrm{~mm}$ applied continuously for 1 hour. Total effluent was reduced by $14 \%$ and $10 \%$ in Expts. 1 and 2, respectively, when 13-mm irrigation was applied in three cycles compared to one continuous irrigation. Container leachate $\mathrm{NO}_{3}-\mathrm{N}$ concentrations from cyclic irrigation were generally less than leachate $\mathrm{NO}_{3}-\mathrm{N}$ concentrations from continuous irrigation treatments. The percentage of applied $\mathrm{N}$ leached as $\mathrm{NO}_{3}-\mathrm{N}$ ranged from $46 \%$ when $13-\mathrm{mm}$ irrigation was applied in three cycles to $63 \%$ when 13-mm irrigation was applied in a single cycle. Leachate $\mathrm{NO}_{3}$-N concentration was reduced as irrigation volume was reduced from 13 to $6 \mathrm{~mm}$ in Expt. 2. Percentage of applied $\mathrm{N}$ leached as $\mathrm{NO}_{3}-\mathrm{N}$ was $63 \%, 56 \%$, and $47 \%$ when $13-\mathrm{mm}$ irrigation was applied in one, two, and three cycles, respectively, compared to $19 \%, 16 \%$, and $15 \%$ when 6-mm irrigation was applied in one, two, and three cycles, respectively. 'Compacta' holly shoot and root growth were minimally affected by cyclic irrigation or irrigation volume.

Successful production of container-grown ornamentals requires adequate nutrients and water in the container medium. Most soilless media, consisting of a high percentage of pine bark, have a low capacity for retaining nutrients and water, and large irrigation quantities result in significant nutrient loss, particularly $\mathrm{NO}_{3}-\mathrm{N}$ (Rathier and Frink, 1989).

Several cultural methods have been evaluated to improve $\mathrm{NO}_{3}-\mathrm{N}$ management in container nurseries (Cox, 1985; Jarrell et al., 1983; Niemiera, 1991; Rathier and Frink, 1989; Stewart et al., 1981). Recently, two commercial nurseries reported a reduction in irrigation volume applied and subsequent irrigation runoff with cyclic irrigation (Daughtry, 1990; Whitesides, 1989). Cyclic irrigation comprises two phases: 1) the operating phase of the irrigation system and 2) the phase in which the

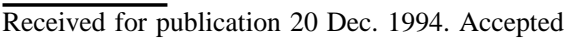
for publication 18 Aug. 1994. This research was supported in part by a grant from the Horticultural Research Institute, Washington, D.C. The cost of publishing this paper was defrayed in part by the payment of page charges. Under postal regulations, this paper therefore must be hereby marked advertisement solely to indicate this fact.

${ }^{1}$ Assistant Professor. Current address: College of Agriculture, Tennessee Technological Univ., Cookeville, TN 38505.

${ }^{2}$ Professor of Horticulture.

${ }^{3}$ Superintendent. irrigation is off (Karmeli and Peri, 1974). To our knowledge, no research has been conducted to determine the influence of overhead
Fig. 1. Water collection module. cyclic irrigation. We conducted two experiments to evaluate the effects of cyclic, overhead irrigation on container leachate and runoff volume, $\mathrm{NO}_{3}-\mathrm{N}$ concentration leached from the container, and plant growth of Ilex crenata 'Compacta' holly.

\section{Materials and Methods}

Apparatus. Water collection modules were constructed to collect container leachate and runoff from the growing areas. Modules were $0.25 \mathrm{~m}$ deep, $1.2 \mathrm{~m}$ wide, and $2.4 \mathrm{~m}$ long (Fig. 1). The module base was 1.9 -cm-thick, pressure-treated plywood, with a funnel installed in one corner to route container leachate to a container outside the module. A second 1.9$\mathrm{cm}$-thick plywood sheet was placed on support beams $(2.5 \times 5.0 \mathrm{~mm})$ near the top of the pressure-treated side boards. All joints were caulked and painted to prevent leakage. Sixteen holes, $15 \mathrm{~mm}$ in diameter and spaced $\approx 18$ $\mathrm{mm}$ apart, were cut in the top plywood sheet, and 2.3-liter nursery containers were recessed about two-thirds of the depth of the container. The containers were suspended in the top sheet of plywood, which allowed container leachate to drain into the module base for collection. A second funnel was installed in one corner of the top plywood sheet to route bed runoff to a collection container outside the module. Modules were supported at a 5\% slope by $20 \times 20 \times 41-\mathrm{mm}$ concrete blocks.

In Expt. 1, the design was a randomized block design with three replications of each irrigation treatment and 16 plants per replication (module). Experiment 2 was a completely randomized design in a $2 \times 3$ factorial $(2$ irrigation volumes $\times 3$ irrigation cycles). Each experimental unit (module) had three replications, with 16 plants at each irrigation treatment with a split-plot of two fertilizer rates.

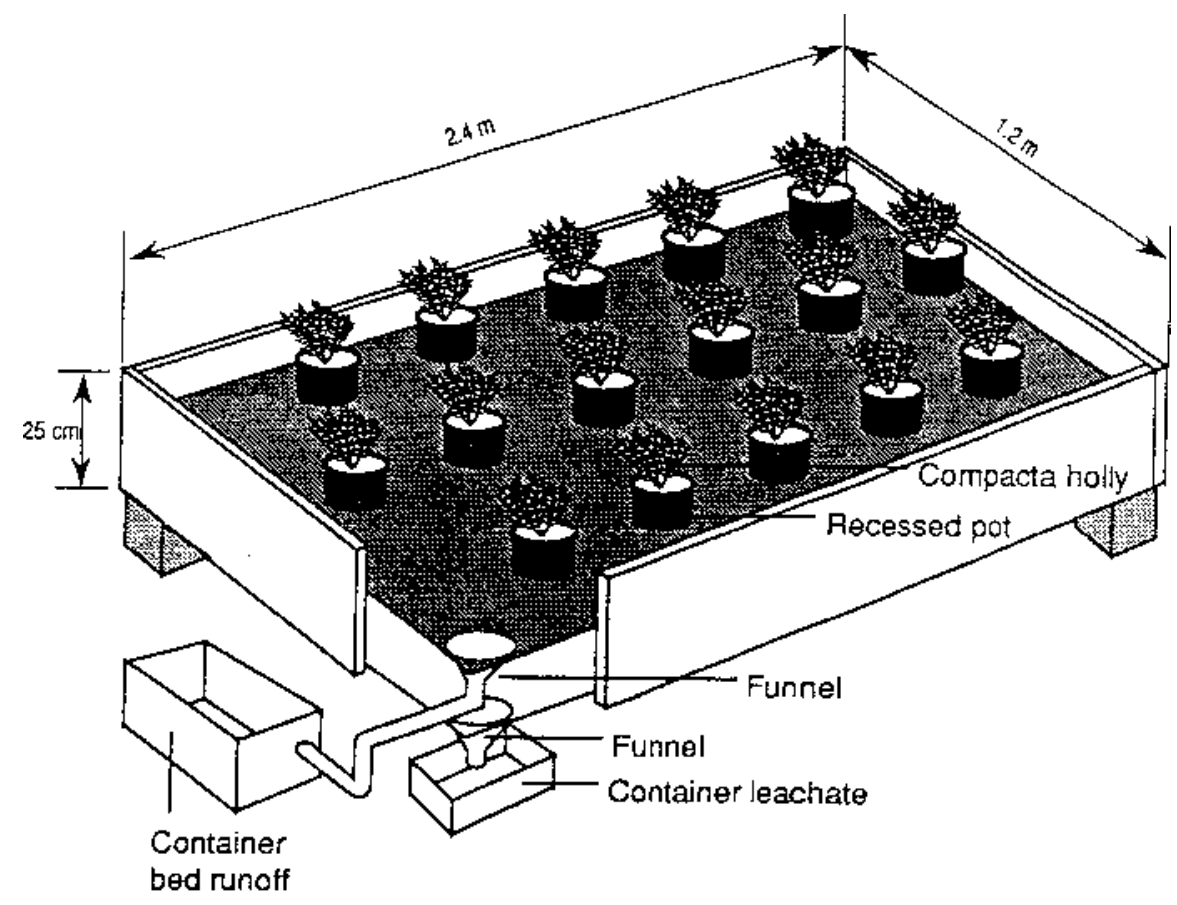


Plant and media preparation. Uniform liners of 'Compacta' holly in 480- $\mathrm{mm}^{3}$ pots were repotted into a 3 pine bark : 1 peat $(\mathrm{v} / \mathrm{v})$ medium in 2.3-liter containers on 26 Mar. 1991 (Expt. 1) and 12 May 1992 (Expt. 2). Medium was amended with $\left(\mathrm{kg} \cdot \mathrm{m}^{-3}\right) 1.2 \mathrm{gyp}-$ sum, 3.6 dolomitic limestone, and 0.9 minor elements (Micromax; Grace-Sierra, Milpitas, Calif). In Expt. 1, 17N-3.1P-10K controlledrelease fertilizer (Osmocote; Grace-Sierra) was incorporated at $8.3 \mathrm{~kg} \cdot \mathrm{m}^{-3}$ into the medium before potting. A second fertilizer application Sylacauga, Ala.) at $5 \mathrm{~g} /$ pot was topdressed on 21 Aug. 1991. In Expt. 2, controlled-release fertilizer at two rates was incorporated into the medium before potting (in $\mathrm{kg} \cdot \mathrm{m}^{-3}$ ): 7.1 [low fertilizer (LF)] and 9.5 [high fertilizer (HF)] of $17 \mathrm{~N}-3.1 \mathrm{P}-10 \mathrm{~K}$. Plants in the LF and HF treatments were topdressed on 14 Sept. 1992 with $17 \mathrm{~N}-3.1 \mathrm{P}-10 \mathrm{~K}$ at 18 and $24 \mathrm{~g} / \mathrm{pot}$, respectively.

Table 1. Irrigation treatments (Expts. 1 and 2).

\begin{tabular}{|c|c|c|c|}
\hline $\begin{array}{l}\text { Irrigation } \\
\text { cycle }^{z}\end{array}$ & $\begin{array}{c}\text { No. } \\
\text { cycles }^{y}\end{array}$ & $\begin{array}{c}\text { Cycle } \\
\text { duration } \\
(\mathrm{min})\end{array}$ & $\begin{array}{l}\text { Total } \\
\text { irrigation } \\
\text { vol }(\mathrm{mm})\end{array}$ \\
\hline \multicolumn{4}{|c|}{ Expt. 1} \\
\hline $1 \mathrm{C} 13$ & --- & 60 & 13 \\
\hline 2CY13 & 2 & 30 & 13 \\
\hline $1 \mathrm{C} 8$ & --- & 40 & 8 \\
\hline $2 \mathrm{CY} 8$ & 2 & 20 & 8 \\
\hline \multicolumn{4}{|c|}{ Expt. 2} \\
\hline $1 \mathrm{C} 13$ & --- & 60 & 13 \\
\hline 2CY13 & 2 & 30 & 13 \\
\hline $3 \mathrm{CY} 13$ & 3 & 20 & 13 \\
\hline $1 \mathrm{C} 6$ & --- & 30 & 6 \\
\hline 2CY6 & 2 & 15 & 6 \\
\hline $3 \mathrm{CY} 6$ & 3 & 10 & 6 \\
\hline
\end{tabular}

${ }^{2} 1 \mathrm{C} 13$, one continuous cycle with 13-mm irrigation $2 \mathrm{CY} 13$ and $3 \mathrm{CY} 13$, two and three cycles, respectively, with $13-\mathrm{mm}$ irrigation; $1 \mathrm{C} 8$, one continuous cycle with 8-mm irrigation; $2 \mathrm{CY} 8$, two cycles with 8-mm irrigation; 1C6, one continuous cycle with 6$\mathrm{mm}$ irrigation; $2 \mathrm{CY} 6$ and $3 \mathrm{CY} 6$ two and three cycles, respectively, with 6-mm irrigation.

${ }^{y}$ All cyclic treatments had a 1-h resting phase between irrigation cycles. of $12 \mathrm{~N}-2.6 \mathrm{P}-4.9 \mathrm{~K}$ (Parker Fertilizer Co.

Particle size distribution of the medium was determined by sieving oven-dried medium through U.S. standard sieves no. 1/4, 4, $7,18,35,60$, and 140 with openings of 6.4 , $4.75,2.8,1.0,0.5,0.25$, and $0.106 \mathrm{~mm}$, respectively. Based on percentage of dry medium weight, medium particles $>4.75$, between 4.75 and 1.0 , and $<1.0 \mathrm{~mm}$ were $28 \%, 60 \%$, and $12 \%$, respectively, in Expt. 1 and 32\%, 58\%, and $10 \%$, respectively, in Expt. 2.

Medium pore space and water-holding capacity were determined from Gessert (1976) and Whitcomb (1979) procedures. Physical properties for medium in Expt. 1 were 60\% total porosity, $22 \%$ airspace, and $38 \%$ waterholding capacity. In Expt. 2, medium had 58\% total porosity, $22 \%$ airspace, and $36 \%$ waterholding capacity. Cation exchange capacities (CEC) were 259 and 375 meq per container (45 and 48 meq per $100 \mathrm{~g}$ medium) for Expts. 1 and 2 , respectively.

Irrigation treatments. Plants were handwatered to saturation at potting, weighed (container mass), placed in the collection modules, and watered with overhead impact sprinklers (model 20BADJ; Rain Bird Sales, Glendora, Calif.). Irrigation was applied to all treatments at 0.9 liter $\cdot \mathrm{s}^{-1}$. The average daily irrigation applied at container nurseries in Alabama is $\approx 15 \mathrm{~mm}$ and ranges from 6 to $22 \mathrm{~mm}$ (Fare et al., 1992). To model irrigation volumes used in nurseries, two irrigation volumes (13 and 8 $\mathrm{mm}$ ) were applied as a continuous application (1C13 and 1C8, respectively) or as two cyclic applications (2CY13 and $2 \mathrm{CY} 8$, respectively) (Table 1). Irrigation was applied to all treatments when container medium in the $1 \mathrm{C} 13$ treatment was estimated at $70 \%$ to $80 \%$ of container capacity. Irrigation was applied between 0700 and $1200 \mathrm{HR}$.

In Expt. 2, plants were irrigated when the container medium for each treatment reached $80 \%$ of container capacity as determined by container mass. Two plants from each treatment and replication were weighed each afternoon (1600 HR) to determine weight loss. Irrigation application was based on weight loss

Table 2. Effects of irrigation method and volume on container leachate and total effluent in the water collection module and growth of 'Compacta' holly (Expt. 1).

\begin{tabular}{|c|c|c|c|c|}
\hline $\begin{array}{l}\text { Irrigation } \\
\text { cycles }^{z}\end{array}$ & $\begin{array}{c}\text { Container } \\
\text { leachate } \\
\text { (liters) }^{\mathrm{y}}\end{array}$ & $\begin{array}{l}\text { Total } \\
\text { effluent } \\
\text { (liters) }^{\mathrm{y}}\end{array}$ & $\begin{array}{l}\text { Growth } \\
\text { index } \\
(\mathrm{mm})^{\mathrm{x}}\end{array}$ & $\begin{array}{c}\text { Shoot } \\
\text { dry wt } \\
(\mathrm{g})\end{array}$ \\
\hline $1 \mathrm{C} 13$ & 3.5 & 30.1 & 32.2 & 76.3 \\
\hline 3CY13 & 2.3 & 25.9 & 35.0 & 66.0 \\
\hline $1 \mathrm{C} 8$ & 1.8 & 21.7 & 31.7 & 69.8 \\
\hline $3 \mathrm{CY} 8$ & 1.1 & 18.5 & 31.0 & 62.5 \\
\hline \multicolumn{5}{|l|}{ Significance } \\
\hline Cyclic & 0.0001 & 0.0001 & 0.005 & 0.002 \\
\hline Irrigation volume & 0.0001 & 0.0001 & 0.001 & 0.031 \\
\hline Cyclic $\times$ irrigation & 0.2070 & 0.2433 & 0.001 & 0.428 \\
\hline \multicolumn{5}{|l|}{ Contrast } \\
\hline $\begin{array}{l}1 \text { cycle vs. } 3 \text { cycles } \\
\text { with } 13 \mathrm{~mm}\end{array}$ & $--{ }^{w}$ & --- & 0.001 & --- \\
\hline 1 cycle vs. 3 cycles & & & & \\
\hline with $8 \mathrm{~mm}$ & --- & --- & 0.223 & --- \\
\hline
\end{tabular}

${ }^{\mathrm{z}} 1 \mathrm{C} 13$, one continuous cycle with 13-mm irrigation; 3CY13, three cycles with 13-mm irrigation; $1 \mathrm{C} 8$, one continuous cycle with 8-mm irrigation; $3 \mathrm{CY} 8$, three cycles with 8-mm irrigation.

${ }^{\mathrm{y}}$ Container leachate and total effluent (container leachate plus irrigation runoff) were collected from each module (16 containers) after each irrigation event.

${ }^{x}$ Growth index $=\left[\right.$ height + width $_{1}+$ width $_{2}\left(\right.$ perpendicular to width $\left.\left.{ }_{1}\right)\right] / 3$.

${ }^{w}$ Dash denotes contrast not tested due to nonsignificant interaction. from container mass at potting. Irrigation was applied the following day between 0500 and 1100 HR. Two irrigation volumes (13 and 6 $\mathrm{mm}$ ) were applied as a continuous application (1C13 and 1C6, respectively) or as two (2CY13 and 2 CY6, respectively) or three (3CY13 and 3CY6) cyclic applications (Table 1).

Tempe pressure cells (Soilmoisture Equipment Corp., Santa Barbara, Calif.) were used to develop a soil moisture release curve. Based on the curve, $\approx 40 \%$ to $50 \%$ of the total water volume was not available to plants (data not shown). Thus, irrigation was applied when $\approx 33 \%$ to $40 \%$ of the available water was lost via evapotranspiration. One plant per treatment per replication was harvested (fresh and dry shoot and root weights were recorded) during the middle of each experiment to recalibrate for container mass due to plant growth.

Water analysis. After one irrigation each week, container leachate and irrigation runoff (irrigation water that fell between the pots) volumes were measured $1 \mathrm{~h}$ after applying irrigation. Leachate was collected on days 1,3 , $5,10,45,60,90,120,150,180$, and 210 in Expt. 1 and days 1, 3, 5, 10, 20, 30, 60, 90, 100, 121, 123, 126, 130, 140, 150, and 180 in Expt. 2. Leachate samples were filtered and refrigerated at $4 \mathrm{C}$. Within 4 weeks, leachate samples were analyzed for $\mathrm{NO}_{3}-\mathrm{N}$ and $\mathrm{NH}_{4}-\mathrm{N}$ with a Wescan ammonia analyzer (model 360; Alltech Associates, Deerfield, Ill.).

Plant harvest. Plants were grown outdoors in full sun for 210 and 180 days in Expts. 1 and 2 , respectively. At termination, shoot growth was analyzed by determining a growth index $\{$ [height + width $1+$ width 2 (perpendicular to width 1)]/3 . Shoots were cut at soil level, oven-dried at 57C, weighed, and analyzed for total $\mathrm{N}$ by a semimicro Kjeldahl method. Root growth was determined by transversely dividing the root ball into three $5-\mathrm{cm}$ increments. In each section, roots were separated from the container medium, washed, and scanned on a Comair root length scanner (Commonwealth Aircraft, Melbourne, Australia). Root samples were oven-dried at 57C and weighed. Roots in the three sections were combined to determine total length and dry weight. In both experiments, additional 'Compacta' holly plants were potted and placed on a conventional growing bed with gravel covering. Data collected from these plants were similar to data collected from 'Compacta' holly grown in the water collection modules. Thus, only data from the module are reported.

\section{Results and Discussion}

Container leachate. During Expt. 1, container leachate volume (per pot per irrigation application) was reduced by $34 \%$ when $13 \mathrm{~mm}$ of water was applied in three cycles instead of in one continuous irrigation (Table 2). Using 8 rather than $13 \mathrm{~mm}$ of water reduced container leachate by $\approx 50 \%$ at each irrigation application (90 to $179 \mathrm{ml} /$ pot). Plants receiving treatment 3CY8 had the least container leachate volume, averaging $67 \mathrm{ml} /$ pot over all sampling dates. 
In Expt. 2, fertility treatment had no effect on container leachate volumes; consequently, fertilizer treatment subplots were combined for analysis. Container leachate volumes were reduced by $18 \%$ when $13 \mathrm{~mm}$ of water was applied as cyclic irrigation (2CY13 and 3CY13) compared to $13 \mathrm{~mm}$ applied as continuous irrigation (Table 3 ). There were similar leachate volumes collected from plants grown with treatments $2 \mathrm{CY} 13$ and $3 \mathrm{CY} 13$. With $6 \mathrm{~mm}$ of water, container leachate volumes were reduced $32 \%$ with cyclic irrigation (2CY6 and 3CY6) compared to continuous irrigation (1C6). Leachate volume was $50 \%$ less with three cyclic applications compared to two cyclic applications.

Irrigation runoff in these tests consisted of water that fell between the containers in the water collection module. These modules present an empirical situation because the typical container bed allows some irrigation water to infiltrate the soil. All runoff water was collected from the modules, so our irrigation runoff values are high compared to those in an actual nursery.

Effluent. Total effluent (container leachate and irrigation runoff) from the module was $\approx 30$ liters when $13 \mathrm{~mm}$ of water was applied in a 1-h continuous application (1C13) (Table 2). This amounts to $1 \mathrm{~mm}$ of water $(77 \%$ of the volume applied) or $>100,000$ liters of effluent/ ha per irrigation application. Total effluent was reduced by $14 \%$ when irrigation was applied in three cycles (3CY13) compared to one continuous application (1C13). When continuous irrigation volume was $8 \mathrm{~mm}$ rather than $13 \mathrm{~mm}$, total effluent was reduced by $28 \%$.

Table 3. Effects of irrigation method and volume on container leachate and total effluent in the water collection module (Expt. 2).

\begin{tabular}{|c|c|c|}
\hline $\begin{array}{l}\text { Irrigation } \\
\text { cycles }^{2}\end{array}$ & $\begin{array}{l}\text { Container } \\
\text { leachate } \\
\text { (liters) }^{\mathrm{y}}\end{array}$ & $\begin{array}{l}\text { Total } \\
\text { effluent } \\
\text { (liters) }^{\mathrm{y}}\end{array}$ \\
\hline $1 \mathrm{C} 13$ & 3.1 & 30.5 \\
\hline 2CY13 & 2.7 & 27.4 \\
\hline $3 \mathrm{CY} 13$ & 2.4 & 27.5 \\
\hline $1 \mathrm{C} 6$ & 0.9 & 15.0 \\
\hline $2 \mathrm{CY} 6$ & 0.8 & 13.7 \\
\hline 3CY6 & 0.4 & 12.5 \\
\hline \multicolumn{3}{|l|}{ Significance } \\
\hline Cyclic & 0.0001 & 0.0001 \\
\hline Irrigation volume & 0.0001 & 0.0001 \\
\hline Cyclic $\times$ irrigation & 0.4374 & 0.0001 \\
\hline \multicolumn{3}{|l|}{ Contrasts } \\
\hline $\begin{array}{l}1 \text { cycle vs. } 2 \text { and } 3 \\
\text { cycles with } 13 \mathrm{~mm}\end{array}$ & 0.0063 & 0.0001 \\
\hline $\begin{array}{l}2 \text { cycles vs. } 3 \text { cycles } \\
\text { with } 13 \mathrm{~mm}\end{array}$ & 0.2874 & 0.9023 \\
\hline $\begin{array}{l}1 \text { cycle vs. } 2 \text { and } 3 \\
\text { cycles with } 6 \mathrm{~mm} \\
2 \text { cycles vs. } 3 \text { cycles } \\
\text { with } 6 \mathrm{~mm}\end{array}$ & 0.0061 & 0.0377 \\
\hline
\end{tabular}

${ }^{\mathrm{z}} 1 \mathrm{C} 13$, one continuous cycle with 13 -mm irrigation; $2 \mathrm{CY} 13$ and 3CY13, two and three cycles, respectively, with 13-mm irrigation; $1 \mathrm{C} 6$, one continuous cycle with 6-mm irrigation; $2 \mathrm{CY} 6$ and $3 \mathrm{CY} 6$, two and three cycles, respectively, with 6-mm irrigation. ${ }^{y}$ Container leachate and total effluent (container leachate plus irrigation runoff) were collected from each module (16 containers) after each irrigation event.
In Expt. 2, total effluent was reduced 10\% when continuous irrigation (1C13) was compared to cyclic irrigation (2CY13 and 3CY13). Continuous irrigation with $6 \mathrm{~mm}$ of water, rather than $13 \mathrm{~mm}$, resulted in $51 \%$ less total effluent. When the continuous application (1C6) was compared to two and three cycles (2CY6 and 3CY6), total effluent was reduced by $13 \%$. About $9 \%$ less total effluent was collected from 3CY6 than from 2CY6.

Nitrate-nitrogen leachate. Leachate volumes were used for subsequent calculations of $\mathrm{NO}_{3}-\mathrm{N}$ leached from containers. Only results from Expt. 2 will be discussed because $80 \%$ to $90 \%$ of the $\mathrm{N}$ leached was in the form of $\mathrm{NO}_{3}-\mathrm{N}$. Also, in Expt. 1 (1991), high rainfall $(73.9 \mathrm{~cm}$ ) occurred during April and May; thus, irrigation was not applied as frequently as during normal conditions, resulting in inconsistent $\mathrm{NO}_{3}-\mathrm{N}$ and $\mathrm{NH}_{4}-\mathrm{N}$ concentrations in container leachate.

Based on $\mathrm{NO}_{3}-\mathrm{N}$ concentrations from the sampling dates and the estimated levels from weekly container leachate volumes, leachate $\mathrm{NO}_{3}-\mathrm{N}$ loss was $\approx 133 \mathrm{mg} /$ pot for the growing season from the HF continuous irrigation (1C13) treatment (Table 4). This indicates that $\approx 63 \%$ of the total applied $\mathrm{N}$ was leached as $\mathrm{NO}_{3}$-N. Nitrate-nitrogen loss was reduced $11 \%$ when $13 \mathrm{~mm}$ of water was applied in two and three cycles (2CY13 and 3CY13), compared to one continuous application. Cox (1985), Jarrell et al. (1983), and Niemiera (1991) reported $\mathrm{NO}_{3}-\mathrm{N}$ leached can be $\leq 50 \%, 64 \%$, and $45 \%$ of applied $\mathrm{N}$, respectively, with conventional irrigation.

Nitrate-nitrogen leached with HF was reduced $\approx 53 \%$ (63 vs. $133 \mathrm{mg} /$ pot) when irrigation volume was $6 \mathrm{~mm}$ (1C6) rather than 13 mm (1C13 in Expt. 2) (Table 4). The amount of $\mathrm{NO}_{3}-\mathrm{N}$ leached was reduced $29 \%$ with 6 $\mathrm{mm}$ cyclic irrigation treatments $(2 \mathrm{CY} 6$ and 3CY6) compared to one continuous application (1C6).

Table 4. Effects of irrigation method and volume on estimated cumulative $\mathrm{NO}_{3}$ - $\mathrm{N}$ leached from containers in the collection module (Expt. 2).

\begin{tabular}{|c|c|c|}
\hline \multirow{2}{*}{$\begin{array}{l}\text { Irrigation } \\
\text { cycles }^{y}\end{array}$} & \multicolumn{2}{|c|}{$\begin{array}{c}\text { Estimated cumulative } \\
\mathrm{NO}_{3}-\mathrm{N} \text { leached } \\
(\mathrm{mg} / \mathrm{pot})^{2}\end{array}$} \\
\hline & $\mathrm{HF}^{\mathrm{x}}$ & $\mathrm{LF}^{\mathrm{w}}$ \\
\hline $1 \mathrm{C} 13$ & 133 & 89 \\
\hline $2 \mathrm{CY} 13$ & 129 & 80 \\
\hline $3 \mathrm{CY} 13$ & 108 & 70 \\
\hline $1 \mathrm{C} 6$ & 63 & 34 \\
\hline 2CY6 & 52 & 28 \\
\hline 3CY6 & 37 & 24 \\
\hline
\end{tabular}

${ }^{2}$ The milligrams per pot of $\mathrm{NO}_{3}-\mathrm{N}$ leached was calculated from concentrations from the 16 sampling dates and container leachate volume. Cumulative $\mathrm{NO}_{3}-\mathrm{N}$ leached was interpolated from the irrigation frequency between sampling dates and, therefore, not amenable to statistical analysis. A total of 88 irrigations were applied.

y $1 \mathrm{C} 13$, one continuous cycle with 13 -mm irrigation; $2 \mathrm{CY} 13$ and $3 \mathrm{CY} 13$, two and three cycles, respectively, with 13-mm irrigation; 1C6, one continuous cycle with 6-mm irrigation; $2 \mathrm{CY} 6$ and $3 \mathrm{CY} 6$, two and three cycles, respectively, with 6-mm irrigation. ${ }^{x} \mathrm{HF}=$ high fertility, $9.5 \mathrm{~kg} \cdot \mathrm{m}^{-3}$.

${ }^{\mathrm{w}} \mathrm{LF}=$ low fertility, $7.1 \mathrm{~kg} \cdot \mathrm{m}^{-3}$.
The percentage of leachate $\mathrm{NO}_{3}-\mathrm{N}$ with $\mathrm{LF}$ followed a trend similar to HF (Table 4). Nitrate-nitrogen loss was $\approx 89 \mathrm{mg} /$ pot in the 1$\mathrm{h}$ continuous irrigation treatment (1C13). This loss indicates $\leq 69 \%$ of the total applied $\mathrm{N}$ was leached as $\mathrm{NO}_{3}-\mathrm{N}$.

Cyclic irrigation treatments (2CY13 and $3 \mathrm{CY} 13$ ) had $\approx 16 \%$ less $\mathrm{NO}_{3}-\mathrm{N}$ loss with $\mathrm{LF}$ than with continuous irrigation (1C13). About $64 \%$ less $\mathrm{NO}_{3}-\mathrm{N}$ was leached from pots receiving the LF rate with 6-mm irrigation compared to pots receiving 13-mm irrigation.

These data indicate that regardless of the fertilizer rate used in plant production, leachable $\mathrm{NO}_{3}-\mathrm{N}$ depends on the applied irrigation volume and the amount of container leachate. For example, with $1 \mathrm{C} 13, \approx 63 \%$ of $\mathrm{N}$ leached as $\mathrm{NO}_{3}$-N with $\mathrm{HF}$ and $\approx 69 \%$ with $\mathrm{LF}$. When irrigation was applied in two cycles (2CY13), $\approx 61 \%$ of $\mathrm{N}$ leached as $\mathrm{NO}_{3}-\mathrm{N}$ in the $\mathrm{HF}$ treatment and $62 \%$ in the LF treatment. When 6 $\mathrm{mm}$ of water was applied in three cycles (3CY6), $\approx 18 \%$ of the $\mathrm{N}$ leached as $\mathrm{NO}_{3}-\mathrm{N}$ in the HF treatment and $19 \%$ in the LF treatment.

Plant growth. In Expt. 1, the 'Compacta' holly growth index and shoot dry weights were higher when plants were irrigated with $13 \mathrm{~mm}$ than with $8 \mathrm{~mm}$ (Table 2). The cyclic treatment resulted in a higher shoot-growth index than the noncyclic treatment at $13 \mathrm{~mm}$.

In Expt. 2, cyclic irrigation and irrigation volume had no effect on the growth index or on shoot dry weight (data not shown). Plants grown with the HF rate had a significantly higher growth index (38.6 vs. $34.7 \mathrm{~mm}$ ) and higher shoot dry weights ( $42.7 \mathrm{vs} .38 .5 \mathrm{~g})$ than plants grown with the LF rate. All cyclic irrigation, fertility rate, and irrigation volume treatment interactions were nonsignificant at $P \leq 0.05$.

The difference in plant response in the two experiments was related to soil moisture when irrigation treatments were applied. During Expt. 1, irrigation treatments were applied when soil moisture was estimated to be between $70 \%$ and $80 \%$ of container capacity. In Expt. 2, irrigation applications were applied when soil moisture was at $80 \%$ of container capacity based on weight loss. Because soil was maintained at a higher moisture level in all treatments in Expt. 2, plant response to cyclic irrigation was similar to continuous irrigation.

Root growth was not influenced by cyclic irrigation or irrigation volume in Expt. 1 (data not shown). Typically, more root dry weight was produced in the upper third of the container than the middle or lower third in all irrigation treatments. There were no differences among treatments for total root dry weight.

In Expt. 2, irrigation volume had little effect on root growth. Plants grown with cyclic irrigation produced $268 \mathrm{~m} /$ plant total root length compared to $326 \mathrm{~m} / \mathrm{plant}$ with noncyclic irrigation (significant at $P \leq 0.05$ ). Plants grown with HF had less root length (289 vs. $353 \mathrm{~m} /$ plant) but more root dry weight $(11.0 \mathrm{vs.} 9.7 \mathrm{~g} /$ plant) than plants grown in the LF treatments (significant at $P \leq 0.05$ ). All cyclic irrigation, irrigation volume, and fertility treatment interactions were nonsignificant at $P \leq 0.05$. 
Foliar $\mathrm{N}$ concentration was not influenced by cyclic irrigation or irrigation volume in either experiment (data not shown). But, in Expt. 2, the foliar $\mathrm{N}$ concentration was higher in plants with $\mathrm{HF}\left(37 \mathrm{~g} \cdot \mathrm{kg}^{-1}\right)$ than in plants grown with LF (32 $\left.\mathrm{g} \cdot \mathrm{kg}^{-1}\right)$. Foliar $\mathrm{N}$ levels were in an acceptable range for both treatments (Gilliam and Smith, 1980).

Our data indicate that quality 'Compacta' holly plants can be grown with irrigation volumes lower than those traditionally applied and that using this procedure can result in container leachate volume reduction. Furthermore, if irrigation is applied in two or three cycles, container leachate volume will be reduced, which results in less $\mathrm{NO}_{3}-\mathrm{N}$ leached than in traditional continuous irrigation. Also, the HF fertilizer treatments produced plants $10 \%$ larger than those under LF, but at the same time had $19 \%$ more $\mathrm{NO}_{3}-\mathrm{N}$ leached. With the current environmental concerns re- garding water quality in container production, cyclic irrigation is a desirable management practice to reduce $\mathrm{NO}_{3}-\mathrm{N}$ loss in container production.

\section{Literature Cited}

Cox, D.A. 1985. Nitrogen recovery by seed geranium as influenced by nitrogen source. HortScience 20:923-925.

Daughtry, B. 1990. Conservation of water and fertilizer using pulse irrigation. Proc. Intl. Plant Prop. Soc. 40:390-393.

Fare, D.C., C.H. Gilliam, and G.J. Keever. 1992. Monitoring irrigation at container nurseries. HortTechnology 2:75-78.

Gessert, G. 1976. Measuring air space and water holding capacity. Ornamentals Northwest 3:5960.

Gilliam, C.H. and E.V. Smith. 1980. Fertilization of container-grown nursery stock. Ohio Coop. Ext. Serv. Bul. 658.
Jarrell, W.M., S.J. Whaley, and B. Miraftabi. 1983. Slow-release fertilizer and water management with container-grown Ligustrum texanum. Scientia Hort. 19:177-190.

Karmeli, D. and G. Peri. 1974. Basic principals of pulse irrigation. J. Irr. Drainage Div., Proc. Amer. Soc. Civil Eng. 100(IR3):309-319.

Niemiera, A.X. 1991. Nitrogen leaching from osmocote as influenced by irrigation amount. Proc. Southern Nurserymen Assn. Res. Conf. 36:84-85.

Rathier, T.M. and C.R. Frink. 1989. Nitrate in runoff water from container grown juniper and alberta spruce under different irrigation and $\mathrm{N}$ fertilization regimes. J. Environ. Hort. 7:32-35.

Stewart, J.A., L.J. Lund, and R.L. Branson. 1981. Nitrogen balances for container-grown privet. J. Amer. Soc. Hort. Sci. 106:565-569.

Whitcomb, C.E. 1979. Plants, pots, and drainage. Ornamental South 1(4):16-19.

Whitesides, R. 1989. El modeno gardens: Innovative solutions to California's irrigation runoff restrictions. GrowerTalks 59:28-36. 